\title{
METHOD VALIDATION OF CAPECITABINE IN API AND PHARMACEUTICAL DOSAGE FROM BY UV SPECTROPHOTOMETRIC METHOD
}

\author{
AYAN KUMAR KAR ${ }^{1,2 *}$, BANHISHIKHA KAR ${ }^{1}$, BEDUIN MAHANTI ${ }^{2}$, CHANDAN KUMAR $^{1}$ \\ ${ }^{1}$ Department of Pharmaceutics, Calcutta Institute of Pharmaceutical Technology and Allied Health Science, Banitabla, Howrah, West Bengal, \\ India. ${ }^{2}$ Department of Pharmaceutics, School of Pharmacy, Techno India University, Kolkata, West Bengal, India. Email: ayancipt@gmail.com
}

Received: 30 January 2020, Revised and Accepted: 11 March 2020

\section{ABSTRACT}

Objective: The simple, rapid spectrophotometric method was developed for the determination of capecitabine, an anticancer drug, in pharmaceutical formulations. Among the approaches, most commonly used targeted mechanism is pH-dependent delivery system which is based on pH gradient of the gastrointestinal tract (GIT) that increases progressively from the stomach.

Methods: The focus of the present study is to similarize the capecitabine drug in bulk form with the marketed tablet (Capegard 500) on the simple, accurate, and precise manner by UV spectrophotometer.

Results: Beer's law was obeyed over a concentration range of 5-30 $\mu \mathrm{g} / \mathrm{mL}$ in $\mathrm{HCl}$ at $\mathrm{pH} 1.2$ and in phosphate buffer at pH 6.8 and 7.4 . The linear regression equations of pure drug were found to be $y=0.0135 x+0.2014, y=0.0147 x+0.2153$, and $y=0.0245 x+0.1507$ in $\mathrm{HCl}$, phosphate buffer at 6.8 and 7.4, respectively, whereas the linear regression equations of marketed tablet were found to be $y=0.0158 x+0.1964, y=0.0192 x+0.2261$, and $y=0.015 x+0.2032$, respectively, and the three methods were validated as per the International Council for Harmonisation guideline (ICH).

Conclusion: The regression values of every equation were found to be above 0.990 which indicated that all the equations were maintaining linearity.

Keywords: Capecitabine, UV spectrophotometric method, Method validation

(C) 2020 The Authors. Published by Innovare Academic Sciences Pvt Ltd. This is an open access article under the CC BY license (http://creativecommons. org/licenses/by/4. 0/) DOI: http://dx.doi.org/10.22159/ajpcr.2020.v13i5.36985

\section{INTRODUCTION}

Cancer is the development of abnormal cells that the body cannot control. It can affect all parts of the body, which means some types are exclusive to women and others affect only men. Cancer treatment is aimed at removing the cancer cells or destroying them in the body with medicines or other agents. Early diagnosis is the key to getting the right treatment. The three most common types of cancer treatment are surgery, radiotherapy, and chemotherapy. Chemotherapy that is generally used to prescribed medicine to treat cancer is generally used when cancer has spread to other areas in the body. As per the data of the World Health Organization, cancer is the second leading cause of death after heart diseases. Among the chemotherapeutic agents, capecitabine is one of the most commonly used.Capecitabine is an orally-administered chemotherapeutic agent used in the treatment of metastatic breast and colorectal cancers. It has the chemical name pentyl [1-(3,4-dihydroxy5-methyl-tetrahydrofuran-2-yl)-5-fluoro-2-oxo-1Hpyrimidin-4-yl] aminomethanoate, as shown in Fig. 1 [1]. It is a white to almost white in color powder with a molecular formula of $\mathrm{C}_{15} \mathrm{H}_{22} \mathrm{FN}_{3} \mathrm{O}_{6}$ and a molecular weight of 359.3. The solubility profile of the drug is very soluble in methanol, ethanol, and acetonitrile and insoluble in water. It works by interfering with the production of proteins necessary for cancer cell growth and reproduction. It acts as a prodrug that was triggered by the enzyme thymidine phosphorylase to act on tumor cells by its cytotoxic moiety, and fluorouracil (FU). The active moiety of capecitabine said to be "targeted" against the cancerous cells [2]. The elimination half-life of both capecitabine and 5 -FU is about $0.89 \mathrm{~h}$, with more than $70 \%$ of the administered dose recovered in urine, largely as a metabolite of 5-FU the absolute bioavailability of capecitabine is $42 \%$. The recommended daily dose is large, i.e., $150 \mathrm{mg} / \mathrm{m}^{2}$. The adverse effects associated with capecitabine include bone-marrow depression, cardiotoxicity, diarrhea, nausea and vomiting, stomatitis, dermatitis, headache, abdominal pain, and constipation [3].
The delivery of this type of drug allows reaching the target cell with the higher drug concentration without absorbing in the gastrointestinal tract. Hence, the successful delivery of drug to the target cell requires protection of the drug from degradation or release in the stomach and then gives controlled release of the drug [4,5]. There are many methods which were developed and validated for the determination of capecitabine from various formulations. In the present study, as capecitabine is used as colon targeted, spectrophotometric method was adopted as an analytical technique to determine the linearity of capecitabine, active pharmaceutical ingredients (API) with the marketed solid dosage form in different buffer solution at different $\mathrm{pH}$. The proposed method was developed and applied for the estimation of capecitabine in pharmaceutical dosage forms. The standardization method for the evaluation of capecitabine was found to be easy, economic, accurate, and reliable. The method found to be specific based on the limit of detection (LOD) and limit of quantification (LOQ) studies and therefore it can be to successfully implement during investigation.

\section{MATERIALS AND METHODS}

\section{Materials}

Capecitabine pure drug was received as a gift sample. Capecitabine marketed tablet (Capegard 500) was purchased from the local market. Potassium dihydrogen phosphate, sodium hydroxide, potassium chloride, and hydrochloric acid $(\mathrm{HCl})$ were purchased from Loba Chemie Pvt. Ltd. All other chemicals and reagents used in the study were of analytical grade.

\section{Instruments}

UV-visible spectrophotometer (Shimadzu 1700, Japan) used with $1 \mathrm{~cm}$ path length quartz cell, analytical balance (Wensar, PGB 200, India), and probe sonicator (PCI analytics, Mumbai, India) were used in this study. 
Preparation of buffer solution at different $\mathrm{pH}$

First, $0.2 \mathrm{M}$ potassium chloride was prepared by dissolving $14.91 \mathrm{~g}$ of potassium chloride in water and make up the volume up to $1000 \mathrm{ml}$. Then, $0.2 \mathrm{M} \mathrm{HCl}$ solution was prepared by dissolving $7.2 \mathrm{ml}$ of $\mathrm{HCl}$ and volume was make up to $1000 \mathrm{ml}$. To prepare the $\mathrm{HCl}$ buffer at $1.2,50 \mathrm{ml}$ of potassium chloride solution placed in $200 \mathrm{ml}$ volumetric flask and add $85 \mathrm{ml}$ of $0.2 \mathrm{M} \mathrm{HCl}$ and make up the volume up to $200 \mathrm{ml}$ using distilled water to get $\mathrm{pH} 1.2[6,7]$.

$27.22 \mathrm{~g}$ of monobasic potassium phosphate was dissolved in distilled water and dilute with distilled water up to $1000 \mathrm{ml}$ to make $0.2 \mathrm{M}$ potassium dihydrogen phosphate buffer solution and in another volumetric flask, $7.9 \mathrm{~g}$ of sodium hydroxide was dissolved in distilled water and make up the volume up to $1000 \mathrm{ml}$ to make $0.2 \mathrm{M}$ sodium hydroxide solution. To prepare the buffer solution, first $50 \mathrm{ml}$ of potassium dihydrogen phosphate solution and add $22.4 \mathrm{~mL}$ of sodium hydroxide solution in $200 \mathrm{ml}$ of volumetric flask and then make up the volume using distilled water to get $\mathrm{pH} 6.8$ [6].

$50 \mathrm{ml}$ of monobasic potassium dihydrogen phosphate solution was taken in $200 \mathrm{ml}$ volumetric flask and then add $39.1 \mathrm{ml}$ of sodium hydroxide solution is dissolved in $200 \mathrm{ml}$ volumetric flask and the make up the volume using distilled water to get pH 7.4 [6].

\section{Preparation of calibration curve of capecitabine pure drug}

The buffer solution was prepared and then the stock solution was prepared by dissolving $10 \mathrm{mg}$ of the drug into different buffer solution, respectively. An aliquot of the sample was taken in a separate volumetric flask and diluted up to $10 \mathrm{ml}$ to get a concentration range of $5-30 \mathrm{mcg} / \mathrm{mL}$ and analyzed for their respective wavelength. Capecitabine in API form was dissolved in different buffer solution at different $\mathrm{pH}$. The solution was scanned for the observed wavelengths for analysis in UV spectrophotometer (Shimadzu 1700, Japan) in the range of $200-400 \mathrm{~nm}$. The wavelength in $0.1 \mathrm{~N} \mathrm{HCl}$ at 1.2 was found to be $295 \mathrm{~nm}$ and in phosphate buffer at 6.8 and $7.4 \mathrm{~nm}$ is $301 \mathrm{~nm}$ [8].

\section{Sample preparation}

Ten tablets (capegard 500) were accurately weighed and crushed. $10 \mathrm{mg}$ equivalent weight of capecitabine was weighed from the crushed tablets and the stock solution of the sample was prepared by dissolving into $\mathrm{HCl}$, phosphate buffer solution at $\mathrm{pH} 1.2,6.8$, and 7.4, respectively. An aliquot sample was taken in centrifuge tube $(10 \mathrm{~mL})$ from each buffer solution and diluted up to $10 \mathrm{~mL}$ to get a concentration range of $5-30 \mathrm{mcg} / \mathrm{ml}$ and analyzed at their respective wavelength $[7,9,10]$.<smiles>CCCCCOC(=O)Nc1nc(=O)n([C@@H]2O[C@H](C)[C@@H](O)[C@H]2O)cc1F</smiles>

Fig. 1: Structure of capecitabine

\section{Method validation}

The side by side equation method was validated by evaluating linearity, precision, LOD, and LOQ according to the International Council for Harmonisation guideline [9,11-15]

\section{Linearity}

From the standard stock solution, $0.5,1.0,1.5,2.0,2.5$, and $3.0 \mathrm{~mL}$ was transferred to different $10 \mathrm{~mL}$ of the centrifuge tube and made up the volume with a buffer solution at $\mathrm{pH} 1.2,6.8$, and 7.4 , respectively. The concentration of capecitabine was found to be $5-30 \mathrm{mcg} / \mathrm{mL}$

\section{Precision}

The precision considers that the closeness of agreement between a series of results decided by inspecting multiple samples of single analyte. The precision of the method was verified by repeatability (system precision) and intermediate (method precision) studies. The system precision study was carried out by three recreate absorbance of capecitabine on the same day and also replicated on the different days to determine the method precision.

\section{LOD and LOQ}

The LOD is the lowest amount of analyte in a sample that can be detected, but not necessarily quantified. LOD and LOQ were calculated using the standard deviation and slope values obtained from the calibration curve of standard and test sample followed by equations 1 and 2 .

$$
\begin{aligned}
& L O D=[3.3 \times\{I / S\}] \\
& L O Q=[10 \times\{I / S\}]
\end{aligned}
$$

Where, $I$ and $S$ indicate the standard deviation of intercept and mean value of slope, respectively.

\section{RESULTS AND DISCUSSION}

Capecitabine is an effectual anticancer agent used in the treatment of breast and colorectal cancers and is a prodrug, that is, enzymatically converted to 5 -FU. The significant estimation of capecitabine is possible by spectroscopic and chromatographic methods as reported. However, most of the method required buffer solution for chromatographic elution. Hence, it becomes essential to develop simple chromatographic method by UV spectrophotometer. In this method, it has been accomplished by progressing and formalizing straightforward, accurate, precise, perceptive, accessible, and selective method for the quantification of capecitabine. The method was developed for the assessment of capecitabine in API and pharmaceutical dosage form. Nearly, all the parameters are validated and studied for the present method.

The proposed method for capecitabine showed the maximum absorbance at a wavelength of $343.37 \mathrm{~nm}$ in $0.1 \mathrm{~N} \mathrm{HCl}$ and similarly, the absorption spectrum of capecitabine in phosphate buffer at different $\mathrm{pH}$ has shown $\lambda \max$ at $340.34 \mathrm{~nm}$. The linearity was observed in the range of $5-10 \mathrm{mcg} / \mathrm{mL}$ for API form as well as for the marketed sample (capegard 500). A graph was drawn by taking the concentration of the

\begin{tabular}{|c|c|c|c|c|c|c|}
\hline \multirow[t]{2}{*}{ S. No. } & \multicolumn{3}{|l|}{ Pure drug } & \multicolumn{3}{|c|}{ Marketed product } \\
\hline & $\begin{array}{l}\text { Absorbance } \\
\text { at pH } 1.2\end{array}$ & $\begin{array}{l}\text { Absorbance } \\
\text { at pH } 6.8\end{array}$ & $\begin{array}{l}\text { Absorbance } \\
\text { at pH } 7.4\end{array}$ & $\begin{array}{l}\text { Absorbance } \\
\text { at pH } 1.2\end{array}$ & $\begin{array}{l}\text { Absorbance } \\
\text { at pH } 6.8\end{array}$ & $\begin{array}{l}\text { Absorbance } \\
\text { at pH } 7.4\end{array}$ \\
\hline 1. & 0.601 & 0.649 & 0.890 & 0.673 & 0.799 & 0.641 \\
\hline 2. & 0.611 & 0.643 & 0.897 & 0.668 & 0.810 & 0.643 \\
\hline 3. & 0.609 & 0.657 & 0.881 & 0.683 & 0.787 & 0.651 \\
\hline Mean & 0.607 & 0.649 & 0.889 & 0.674 & 0.798 & 0.645 \\
\hline SD & 0.004 & 0.005 & 0.006 & 0.006 & 0.009 & 0.004 \\
\hline$\% \mathrm{RSD}$ & 0.658 & 0.770 & 0.674 & 0.890 & 1.127 & 0.620 \\
\hline
\end{tabular}

Table 1: Method precision data for pure capecitabine and marketed sample (capegard 500)

RSD: Relative standard deviation $(\mathrm{n}=3)$ 
drug solutions on the X-axis and the corresponding absorbance values on the Y-axis for the data obtained in different buffer solution, respectively, and the calibration curves are shown in Fig. 2. The linear regression equations were found to be $y=0.0135 x+0.2014, y=0.0147 x+0.2153$, and $y=0.0245 x+0.1507$ in $\mathrm{HCl}$, phosphate buffer at 6.8 and 7.4, respectively, whereas the linear regression equations of marketed tablet (capegard 500) were found to be $y=0.0158 x+0.1964, y=0.0192 x+0.2261$, and $y=0.015 x+0.2032$, respectively. Linearity suggests that the test results which were directly proportional to the concentration of analyte in the sample within the range specified. The correlation coefficient $\left(r^{2}\right)$ value of the drug in API form was found to be $0.997,0.998$, and 0.999 and the correlation coefficient $\left(\mathrm{r}^{2}\right)$ value of drug in marketed sample was found to be $0.999,0.997$, and 0.996 in $0.1(\mathrm{~N}) \mathrm{HCl}$ at 1.2 , phosphate buffer at 6.8 , and phosphate buffer at 7.4 , respectively.

The $\%$ of relative standard deviation for three replicates was found to be $<2 \%$ for both method and system precision, as given in Tables 1-3, respectively. The result of LOD and LOQ showed in Table 4 was found to be satisfied at different $\mathrm{pH}$. The experimental results of the validation of the proposed method are shown that those are valid and error free.

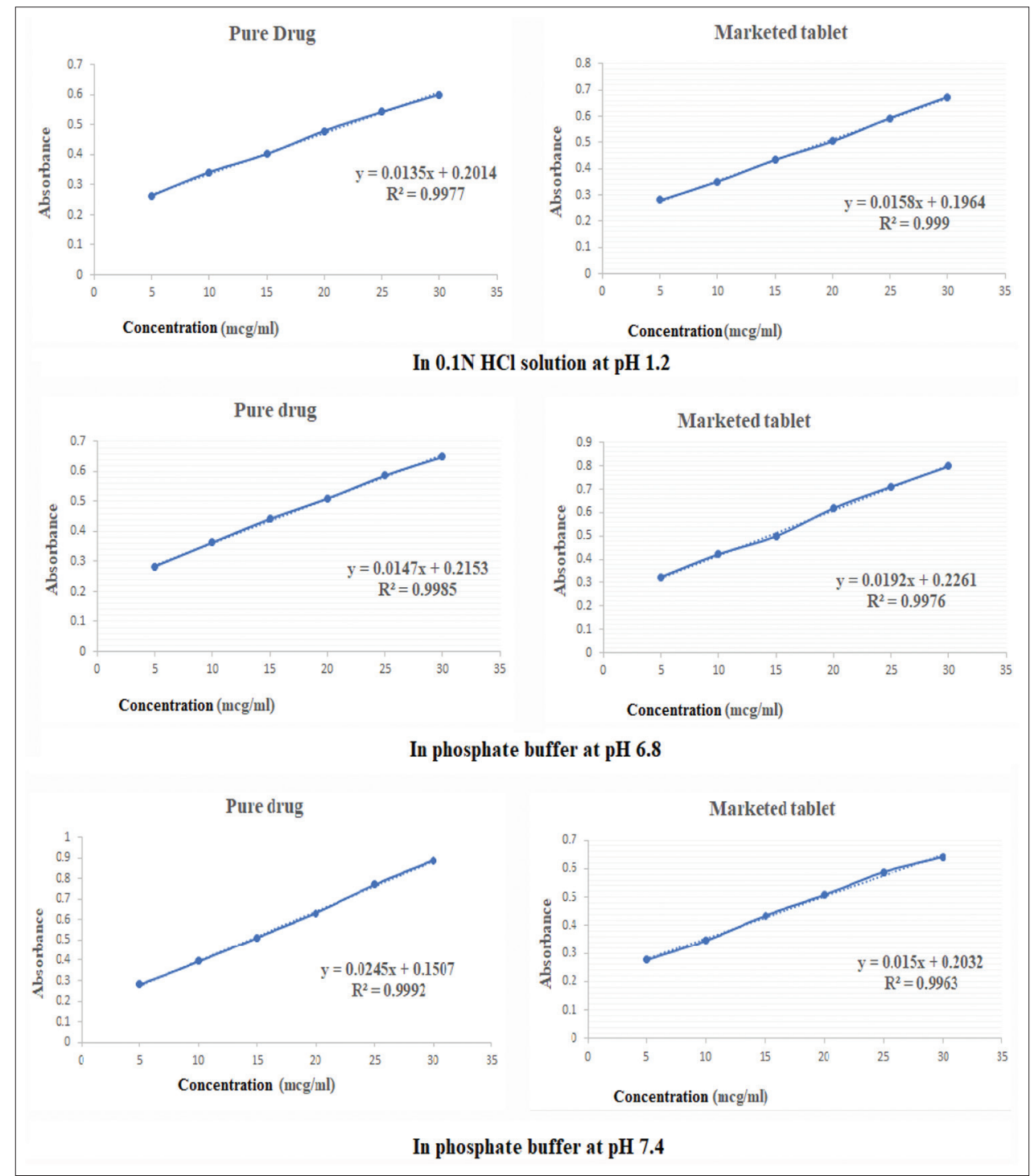

Fig. 2: Calibration curve of pure capecitabine and marketed tablet (capegard 500) in different buffer solution, respectively

Table 2: System precision data for capecitabine in pure form

\begin{tabular}{|c|c|c|c|c|c|c|c|c|c|}
\hline \multirow[t]{2}{*}{ S. No. } & \multicolumn{3}{|c|}{ Absorbance at pH 1.2} & \multicolumn{3}{|c|}{ Absorbance at pH 6.8} & \multicolumn{3}{|c|}{ Absorbance at pH 7.4} \\
\hline & Day 1 & Day 2 & Day 3 & Day 1 & Day 2 & Day 3 & Day 1 & Day 2 & Day 3 \\
\hline 1. & 0.601 & 0.689 & 0.713 & 0.649 & 0.608 & 0.623 & 0.890 & 0.816 & 0.756 \\
\hline 2. & 0.611 & 0.699 & 0.718 & 0.643 & 0.598 & 0.644 & 0.897 & 0.833 & 0.732 \\
\hline 3. & 0.609 & 0.694 & 0.695 & 0.657 & 0.619 & 0.619 & 0.881 & 0.851 & 0.767 \\
\hline Mean & 0.607 & 0.694 & 0.708 & 0.649 & 0.608 & 0.628 & 0.889 & 0.833 & 0.751 \\
\hline SD & 0.004 & 0.004 & 0.009 & 0.005 & 0.008 & 0.010 & 0.006 & 0.014 & 0.014 \\
\hline$\%$ RSD & 0.658 & 0.576 & 1.27 & 0.770 & 1.31 & 1.59 & 0.674 & 1.68 & 1.86 \\
\hline
\end{tabular}

RSD: Relative standard deviation ( $\mathrm{n}=3$ ) 
Table 3: System precision data for capecitabine (marketed sample)

\begin{tabular}{|c|c|c|c|c|c|c|c|c|c|}
\hline \multirow[t]{2}{*}{ S. No. } & \multicolumn{3}{|c|}{ Absorbance at pH 1.2} & \multicolumn{3}{|c|}{ Absorbance at pH 6.8} & \multicolumn{3}{|c|}{ Absorbance at pH 7.4} \\
\hline & Day 1 & Day 2 & Day 3 & Day 1 & Day 2 & Day 3 & Day 1 & Day 2 & Day 3 \\
\hline 1. & 0.673 & 0.711 & 0.738 & 0.799 & 0.719 & 0.753 & 0.641 & 0.581 & 0.649 \\
\hline 3. & 0.683 & 0.747 & 0.732 & 0.787 & 0.691 & 0.738 & 0.651 & 0.556 & 0.641 \\
\hline Mean & 0.674 & 0.716 & 0.729 & 0.798 & 0.705 & 0.750 & 0.645 & 0.571 & 0.638 \\
\hline SD & 0.006 & 0.022 & 0.007 & 0.009 & 0.011 & 0.008 & 0.004 & 0.010 & 0.009 \\
\hline$\%$ RSD & 0.890 & 0.890 & 0.960 & 1.127 & 1.560 & 1.066 & 0.620 & 1.751 & 1.410 \\
\hline
\end{tabular}

RSD: Relative standard deviation $(\mathrm{n}=3)$

Table 4: Detection and quantification data of capecitabine (API) and marketed sample (capegard 500)

\begin{tabular}{llll}
\hline $\mathbf{p H}$ & Brand name & LOD & LOQ \\
\hline 1.2 & API & 2.098 & 6.36 \\
& Capegard 500 & 0.165 & 0.05 \\
6.8 & API & 0.0462 & 0.14 \\
& Capegard 500 & 0.036 & 0.110 \\
7.4 & API & 0.663 & 2.01 \\
& Capegard 500 & 0.026 & 0.080 \\
\hline
\end{tabular}

LOD: Limit of detection, LOQ: Limit of quantification, API: Active

pharmaceutical ingredients

\section{CONCLUSION}

From the results of the analysis, it can be concluded that the proposed method is precise, easy, accurate, sensitive, and selective for the quantification of capecitabine from its marketed formulations. It can be used for the biopharmaceutical studies with slight modification.

\section{ACKNOWLEDGMENT}

I am sincerely thankful to the management, principal, and vice-principal of Calcutta Institute of Pharmaceutical Technology and AHS to provide all the facilities for successful completion of my work.

\section{AUTHORS' CONTRIBUTIONS}

Dr. Beduin Mahanti and Ayan Kumar Kar both are designed the projected work. Ayan Kumar Kar and Banhishikha Kar are involved in the experiments and writing the manuscript. Chandan Kumar involved in the experimental work. Ultimately, all the authors have an equal contribution.

\section{CONFLICTS OF INTEREST}

We, all authors report no conflicts of interest. The authors are responsible for the content and writing of this article.

\section{AUTHORS' FUNDING}

Nil.

\section{REFERENCES}

1. Merck.: The Merck Index. Merck Research Laboratories., $13^{\text {th }}$ ed.: USA: Merck and Co. Inc.; USA: 2001.

2. Bhatia MS, Raut JN, Barve AC, Patil PS, Jadhav SD. HPLC assay method development and validation for quantification of capecitabine in tablets and forced degradation samples. Marmara Pharm J 2017;21:660-8.

3. Dooley M, Goa KL. Capecitabine. Vol. 58. Berlin: Springer; 1999. p. 69-76.

4. Sharma N, Harikumar SL. Polymers for colon targeted delivery: A review. Int J Drug Dev Res 2013;5:21-31.

5. Amidon A, Brown JE, Dave VS. Colon targeted oral drug delivery systems: Design trends and approaches. AAPS PharmSciTech 2015;16:731-41.

6. Available from: https://www.pharmaguideline.com/2010/09/ preparation-of-buffer-solutions.html. [Last accessed on 2019 Sep 02].

7. Mondal S, Narendra R, Ghosh D, Ganapaty S. Development and validation of RP-HPLC and UV spectrophotometric methods for the quantification of capacitabine. Int J Pharm Pharm Sci 2016;5:279-87.

8. Kumbhar SC, Salunkhe VR. UV spectrophotometric method development for capecitabine in eudragit and chitosan based microspheres and its validation. Ind J Pharm Bio Res 2013;1:32-8.

9. Sereya K, Latha ST, Kamalakannan D, Jambulingam M. A new UV spectrophotometric method development and validation for erlotinib by derivative spectroscopy. Int J Pharm H Care Res 2013;1:23-7.

10. Gadiya H, Maheshwari M, Dashora A. UV analytical method development and validation for simultaneous estimation of dapoxetine hydrochloride and sildenafil citrate in tablet dosage form. Asian J Pharm Clin Res 2019;1:328-31.

11. Sawsan A, Razeq A, Demerdash AO, Sanabary FE. HPLC, densitometric and visible- spectrophotometric determination of triclabendazole and ivermectin. Int J Pharm Res 2016;13:1-14.

12. Saravanan VS, Rao BM. Analytical method development and validation for the determination of erlotinib hydrochloride bulk and in pharmaceutical dosage form. J Drug Deliv Ther 2013;3:50-4.

13. Limbani RK, Jignasa M, Pashat Y. Simultaneous equation method for the estimation of ivermectin and clorsulon in their combined pharmaceutical dosage form by UV-visible spectrophotometry. Int Bulletin Drug Res 2014;4:131-9.

14. Pallavi K, Srinivasa BP, Kishore BG. Development and validation of UV spectrophotometric method and RP-HPLC method for estimation of capecitabine in bulk and tablet dosage forms. Int J Appl Pharm 2016;8:24-9.

15. Basha SS, Manikanta S, Jahnavi T. UV Spectrophotometric determination of rupatadine fumarate in bulk and tablet dosage form by using single point standardization method. Int J Pharm Pharm Sci 2019; 7:120-4. 